\title{
Pengaruh Independensi, Pengalaman, Profesionalisme, dan Komitmen Organisasi Pemeriksa Pajak terhadap Kualitas Audit Pajak di Kanwil DJP Jakarta Khusus
}

\author{
Muhamamad Abdul Fatah ${ }^{1}$, Adi Wiratno ${ }^{2}$, Arles Parulian Ompusunggu ${ }^{3}$ \\ ${ }^{1.3}$ Universitas Pancasila, Jl. Srengseng Sawah, Jagakarsa, Jakarta Selatan, 12640 \\ ${ }^{3}$ Universitas Jenderal Soedriman, Jl. HR. Boenyamin 708, Grendeng, Purwokerto Utara, Jawa Tengah 53122
}

\section{INFO ARTIKEL}

\section{JEL Classsification:}

Keywords:

audit quality of

tax, experience,

independence,

organizational

commitment,

professionalism.

\section{AB STRACT}

This study was conducted to test the effect of independence, experience, professionalism, and organizational commitment of tax auditor on audit quality of tax. The population in this study is functional tax auditor in Kanwil DJP Jakarta Khusus. The sampel used in this study were 139 of tax auditor at random, because researchers used random sampling methods in the selection of the sampel. While the methods of data analysis and multiple linear regression analysis with the help of software IBM SPSS 20.0. Quantitative data were collected through a questionnaire which was converted into interval data through the transformation of MSI so it can be analyzed statistically. The results showed variabel independence, experience, professionalism, and organizational commitment of tax auditor simultaneously effect on audit quality of tax. Partially, only independence, experience, and organizational commitment have a significant effect on audit quality of tax, but variabel professionalism isn't have a significant effect on audit quality of tax.

\section{A B S T R A K}

Penelitian ini dilakukan untuk menguji secara empiris pengaruh independensi, pengalaman, profesionalisme dan komitmen organisasi pemeriksa pajak terhadap kualitas audit pajak. Populasi dalam penelitian ini adalah fungsional pemeriksa pajak di Kanwil DJP Jakarta Khusus. Sampel yang digunakan dalam penelitian ini sebanyak 139 fungsional pemeriksa pajak secara random, karena peneliti menggunakan metode Random Sampling dalam pemilihan sampelnya. Sedangkan metode analisis data menggunakan analisis deskripsi dan analisis regresi linear berganda dengan bantuan software IBM SPSS 20.0, dengan data kuantitatif yang dikumpulkan melalui kuesioner yang dikoversi menjadi data interval melalui transformasi MSI sehingga dapat dianalisis secara statistik. Hasil penelitian menunjukkan variabel independensi, pengalaman, profesionalisme dan komitmen organisasi pemeriksa pajak berpengaruh secara simultan terhadap kualitas audit pajak. Secara parsial hanya independensi, pengalaman dan komitmen organisasi yang berpengaruh signifikan terhadap kualitas audit pajak, tetapi varibel profesionalisme tidak berpengaruh secara signifikan terhadap kualitas audit pajak.

*Email Korespondensi: 'atah.ryuk@gmail.com, ${ }^{2}$ adiwaratno08@yahoo.com, ${ }^{3}$ indotoxsolution@gmail.com 


\section{Pendahuluan}

Dalam rangka meningkatkan efisiensi, efektifitas dan kinerja pemeriksaan guna mencapai tujuan pemeriksaan sehingga dapat meningkatkan kepatuhan wajib pajak. Dirjen Pajak menetapkan rencana dan strategi penyelesaian pemeriksaan tahun 2013 dalam Surat Edaran Dirjen Pajak Nomor SE-11/ PJ/2013 yang menetapkan rencana penerimaan dari hasil pemeriksaan secara nasional sebesar Rp. 18.462.531.170.000,-. Dari rencana nasional se-besar tersebut Kanwil Jakarta Khusus mendapat rencana sebesar Rp. 3.770.792.220.556,-. Untuk mencapai rencana penerimaan pajak dari pemeriksaan tersebut, rencana penyelesaian pemeriksaan tahun 2013 ditetapkan sebanyak 26.838 LHP konversi. Berdasarkan hal tersebut, diketauhi bahwa beban tugas pemeriksa pajak untuk menyelesaikan pemeriksaan pajak tahun 2013 sangat tinggi. Dimana setiap penugasan pemeriksaan pajak harus dapat diselesaikan oleh pemeriksa pajak.

Penelitian (Darosi, 2009) mengemukakan bahwa adanya target penerimaan dari kegiatan pemeriksaan pajak yang dapat mempengaruhi perilaku pemeriksa pajak. Pemeriksa pajak akan cenderung lebih berorientasi pada upaya memaksimalkan koreksi atau temuan pemeriksaan pajak yang berpotensi menambah penerimaan Negara. Fakta di lapangan menunjukkan bahwa pemeriksa yang dapat menghasilkan penerimaan pajak yang tinggi akan berusaha menghasilkan koreksi dengan tujuan untuk mengejar penerimaan yang kadang akan mengabaikan faktor obyektivitas dan kualitas bukti auditnya.

Fenomena yang terjadi ini mengindikasikan lemahnya penegakan hukum pajak dalam pelaksanaan pemeriksaan pajak, terlihat dengan adanya pelanggaran prosedur dalam pemeriksaan pajak (Negoro, 2011). Selain itu proses pemeriksaan pajak belum sepenuhnya efektif ditandai dengan adanya manipulasi pemeriksaan pajak dengan adanya peran aparat pajak yang tidak professional, kurang kemampuan dan integritas serta tidak berkomitmen terhadap organisasinya. Beberapa fiskus yang kerap disebut sebagai oknum sering kali bertindak tidak adil alias semena-mena terhadap Wajib Pajak. Tak jarang, mereka melakukannya bukan untuk kepentingan Negara melainkan hanya demi kepentingan dan keuntungan pribadi. Jika tindakan menyimpang yang dilakukan oleh seorang oknum tidak merugikan pendapatan Negara, maka mereka bisa bebas meskipun tindakannya itu merugikan Wajib Pajak (Maharani dan Herawati, 2010).

Angelo (1981) menekankan bahwa kualitas audit dalam pemeriksaan pajak lebih ditekankan pada hasil pemeriksaan yang memiliki kompeten didukung dengan bukti audit kuat serta dapat diselesaikan dengan tepat waktu. Kompetensi, yaitu dimana tingkatan bukti dapat meyakinkan, dipercaya, atau dipegang oleh pemeriksa. Kecukupan bukti, yaitu jumlah bukti yang diperoleh juga menentukan kuat tidaknya bukti. Ketepatan bukti, berkaitan dengan saat bukti dikumpulkan atau berkaitan dengan periode yang dicakup dalam pemeriksaan.

Independensi dalam pemeriksaan pajak merupakan sikap yang diharapkan dari seorang pemeriksa pajak dalam melaksanakan tugasnya sesuai dengan standar pemeriksaan yang bertujuan untuk menguji kelayakan secara keseluruhan dan tujuan audit lain. Mulyadi (2011) mendefinisikan independensi sebagai keadaan bebas dari pengaruh, tidak dikendalikan oleh pihak lain, tidak tergantung pada orang lain.

Seorang pemeriksa pajak dalam menjalankan tugasnya harus menjalani berbagai pelatihan teknis yang cukup yang mencakup aspek teknis maupun pendidikan umum. Dalam penelitian Singgih dan Bawono (2010) mengatakan bahwa pengalaman merupakan suatu proses pembelajaran dan penambahan perkembangan potensi bertingkah laku baik dari pendidikan formal atau bisa juga diartikan sebagai suatu proses yang membawa seseorang kepada suatu pola tingkah laku yang lebih tinggi. Oleh karena itu, pemeriksan pajak 
yang mempunyai banyak pengalaman dalam jabatannya lebih mudah memecahkan masalah yang ditentukan dibandingkan dengan sedikit pengalamannya (Zamal Firdaus, 2009).

Standar professional pemeriksa pajak didasarkan pada pedoman pemeriksaan pajak sebagaimana dalam keputusan Menkeu Nomor 17/PMK.03/2013 tentang tata cara pemeriksaan pajak. Sejalan dengan ketentuan yang dimaksud, penelitian professionalisme pajak ini di evaluasi berdasarkan parameter yang akan diukur. Dengan diberlakukannya berbagai keputusan yang mengatur tata pelaksanaan pemeriksaan pajak diharapkan pemeriksa pajak memiliki kualitas yang baik. Berdasarkan Peraturan Menteri Keuangan No. 17/PMK.03/2013 tentang tata cara pemeriksaan pajak pasal 7 ayat (92) huruf (b) disebutkan bahwa pemeriksaan dilakukan oleh pemeriksa pajak yang jujur dan bersih dari tindakan-tindakan tercela.

Dalam menghasilkan kualitas audit yang baik, maka auditor harus berkomitmen terhadap organisasinya. Komitmen merupakan salah satu konsistensi dari wujud keterkaitan seseorang terhadap suatu hal. Komitmen merupakan salah satu pendukung suatu kinerja yang professional. Carolita dan Rahardjo (2012) dalam penelitiannya menyatakan tingkat komitmen organisasi yang lebih tinggi dapat meningkatkan kualitas audit.

Dari latar belakang tersebut sangat penting untuk memperoleh kualitas audit yang baik agar tidak terjadi penyelewengan dari wajib pajak maupun auditor itu sendiri. Oleh karena itu cukup menarik dan relevan jika pengaruh Independensi, Pengalaman, Profesionalisme, dan Komitmen Organisasi Pemeriksa Pajak terhadap Kualitas Audit pajak diangkat sebagai kajian akademik secara ilmiah.

\section{Telaah Teori dan Pengembangan Hipotesis}

Jensen dan Meckling (1976) menjelaskan hubungan keagenan di dalam teori agensi (agency theory) bahwa perusahaan merupakan kumpulan kontrak (nexus of contract) antara pemilik sumber daya ekonomis (principal) dan manajer (agent) yang mengurus penggunaan dan pengendalian sumber daya tersebut. Dalam penelitian ini yang dimaksudkan dengan prinsipal adalah pemerintah/negara yang mempunyai hak untuk menarik pajak pada warganegara, demi kepentingan pembangunan nasional. Agen yang dimaksud dalam artikel ini adalah para pemungut dan pemeriksa pajak yang turun langsung ke lapangan menghadapi para pembayar pajak atau wajib pajak. Dalam proses selanjutnya jika kedua belah pihak mempunyai visi yang sama yaitu mengoptimalkan pajak, maka diharapkan agen akan bertindak sesuai dengan kepentingan prinsipal, mempunyai hak untuk menarik pajak pada warganegara demi kepentingan pembangunan nasional. Akan tetapi dalam prakteknya dilapangan seringkali pemungut atau pemeriksa pajak sebagai seorang agen tidak bertindak seperti kepentingan prinsipalnya. Kondisi tersebut terjadi ketika pihak agen bisa mendapatkan keuntungan pribadi yang lebih besar justru ketika agen tidak menjalankan kepentingan prinsipalnya.

Dalam teori Disonansi Kognitif(West, 2007) dinyatakan bahwa disonansi kognitif merupakan perasaan ketidaknyamanan yang mengakibatkan oleh sikap, pemikiran, dan perilaku yang tidak konsisten. Sikap, pemikiran, dan perilaku yang tidak konsisten ini dapat dikurangi dengan perubahan yang menghilangkan inkonsistensi. Teori ini berpendapat bahwa disonansi akan memotivasi orang untuk mengambil langkah demi mengurangi ketidaknyamanan. Oleh karena itu ketika sikap, keyakinan, dan perilaku seseorang tidak konsisten maka orang itu akan merasa disonan.

Definisi menurut Undang-undang Nomor 6 Tahun 1983 sebagaimana telah diubah dengan Undang-undang Nomor 16 Tahun 2009 menjelaskan bahwa pemeriksaan pajak adalah serangkaian kegiatan menghimpun dan mengolah data, keterangan dan atau bukti yang dilaksanakan secara objektif dan professional 
berdasarkan standar pemeriksaan untuk menguji kepatuhan pemenuhan kewajiban perpajakan. Pemeriksaan pajak bertujuan menguji kepatuhan wajib pajak dalam melaksanakan kewajiban perpajakannya, pemerintah perlu memerlukan pengawasan melalui pemeriksaan terhadap kepercayaan yang telah diberikan kepada masyarakat yaitu wajib pajak. Hasil pemeriksaan pajak diharapkan memberikan detterent effect kepada wajib pajak sehingga kepatuhannya didalam pemenuhan kewajibannya menjadi lebih baik ditahun-tahun mendatang (Hutagaol, 2007). Dalam pemeriksaan pajak, kualitas pemeriksa pajak sangat dipengaruhi oleh ragamnya latar belakang pendidikan dan pengalamnya, hal tersebut sangat berpengaruh terhadap pelaksanaan pemeriksa pajak. Solusi untuk masalah kesenjangan kualitas pemeriksa adalah melalui pendidikan dan pelatihan secara berkesinambungan dan sistem mutasi yang terencana serta penerapan reward and punishment. Sarana dan prasarana sangat membantu pemeriksa dalam mengolah data untuk tujuan analisa dan perhitungan pajak.

Ruang lingkup pemeriksaan bisa juga disebut audit scope. Hanya saja, ruang lingkup pemeriksaan pajak terkait dengan kewajiban SPT yang disampaikan Wajib Pajak. Sedangkan kewajiban SPT tersebut terkait periode tertentu sebagaimana dijelaskan pada peraturan Menteri Keuangan Nomor 17/PMK.03/2013. Pertama, satu atau beberapa bulan (masa), yaitu ruang lingkup untuk menguji kewajiban pemungutan dan pemotongan. Termasuk kewajiban pemotongan dan pemungutan adalah PPn, PPnBM, PPh pasal 21, PPh Pasal 22, PPh pasal 23, dan PPh Pasal 4(2). Kedua, bagian tahun pajak, yaitu ruang lingkup utuk menguji kewajiban $\mathrm{PPh}$ Badan atau PPh OP.

Standar pemeriksaan pajak meliputi standar umum, standar pelaksanaan pemeriksaan, dan standar pelaporan hasil pemeriksaan (PER23/PJ/2013). Standar umum pemeriksaan merupakan standar yang bersifat pribadi dan berkaitan dengan persyaratan pemeriksa pajak dan mutu pekerjaannya. Standar pelaksanaan pemeriksaan harus didahului dengan persiapan yang baik sesuai dengan tujuan pemeriksaan, yang paling sedikit meliputi kegiatan mengumpulkan dan mempelajari data wajib pajak, menyusun rencana pemeriksaan (audit plan), dan menyusun program pemeriksaan serta mendapat pengawasan yang seksama.

Auditor yang independen adalah auditor yang tidak memihak dan tidak dapat diduga memihak, sehingga tidak merugikan pihak manapun. Dalam melaksanakan suatu tugas yaitu pemeriksaan yang dilakukan oleh seorang yang telah diberikan kepercayaan oleh klien dan para pemakai laporan keuangan untuk membuktikan kewajaran dari sebuah laporan keuangan yang telah disusun dan disajikan oleh para klien. Maka dalam memberikan pendapat mengenai kewajaran atas laporan keuangan, seorang auditor harus mempunyai sikap independen terhadap kepentingan klien, para pemakai laporan, stakeholder, maupun terhadap kepentingan auditor itu sendiri (Carolita \& Rahardjo, 2012).

Pengalaman kerja auditor penting diperlukan dalam rangka kewajiban seseorang auditor terhadap tugasnya untuk memenuhi standar umum audit, Pengetahuan seorang auditor itu dimulai dengan pendidikan formal, yang diperluas melalui pengalaman-pengalaman yang selanjutnya dilakukan dalam bentuk praktek (Carolita \& Rahardjo, 2012). Pengalaman auditor akan terus meningkat seiring dengan makin banyaknya audit yang dilakukan serta kompleksitas tranksaksi keuangan perusahaan yang diaudit sehingga akan menambah dan memperluas pengetahuannya dibidang akuntansi dan auditing. Maka jika seorang auditor memiliki pengalaman yang banyak, penilaiannya akan mencerminkan kualitas yang baik dari sebuah perusahaan yang diperiksa (Salim, 2011).

Profesionalisme auditor merupakan suatu komitmen yang terbentuk dari dalam seorang professional, tanpa paksaan dari siapapun dan secara sadar bertanggungjawab terhadap 
profesinya. Seseorang yang melaksanakan sebuah pekerjaan secara ikhlas maka hasil pekerjaan tersebut akan cenderung lebih baik daripada seseorang yang melakukan dengan terpaksa (Singgih \& Bawono, 2010). Hal ini menunjukkan bahwa auditor dalam melaksanakan tugas audit wajib menggunakan kemahiran profesionalnya secara cermat dan seksama. Penggunaan kemahiran professional secara cermat dan seksama berarti menggunakan pertimbangan yang sehat dalam menentukkan lingkup audit, memilih metodologi, pengujian, dan prosedur audit, serta dalam melakukan penilaian dan melaporkan hasil audit (Primaningsih, 2010).

Komitmen Organisasi pada dasarnya sangat dipengaruhi oleh beberapa faktor yang berhubungan dengan lingkungan kerja, komitmen organisasi sering di identifikasikan dengan mensyaratkan beberapa tingkat persetujuan dengan tujuan dan nilai organisasi atau profesi, termasuk moral dan nilai etika. Oleh karena itu, komitmen akan menimbulkan rasa ikut memiliki bagi auditor terhadap organisasi. Komitmen organisasi adalah hubungan antara karyawan dengan organisasi dengan ditunjukkan adanya keinginan kuat untuk mempertahankan keanggotannya, menerima nilai dan tujuan organisasi. Jadi semakin tinggi komitmen organisasi seorang pemeriksa pajak maka semakin tinggi kualitas audit yang dilakukan (Carolita \& Rahardjo, 2012).

Kualitas hasil pemeriksaan pajak merupakan aspek penting dalam meningkatkan penerimaan Negara dari sektor pajak. Apabila wajib pajak dapat bekerjasama dengan pemeriksa pajak bersedia diperiksa, memberikan data yang diperlukan serta memberi akses untuk dilakukan pengujian fisik serta tindakan tindakan yang kooperatif maka akan semakin mempermudah untuk pemeriksa pajak dalam bertugas. Tidak hanya dari pihak wajib pajak melainkan dari pihak pemeriksa pajak harus mengikuti standar pemeriksaan pajak diantaranya telah mendapat pendidikan dan pelatihan teknis yang cukup serta memiiki keterampilan sebagai pemeriksa pajak, dan menggunakan keterampilannya secara cermat dan seksama, jujur dan bersih dari tindakan-tindakan tercela serta senantiasa mengutamakan kepentingan Negara dan taat terhadap berbagai ketentuan peraturan perundang-undangan termasuk taat terhadap batasan waktu yang ditetapkan (Darosi, 2009).

\section{H1: Independensi Berpengaruh Positif Ter- hadap Kualitas Audit Pajak}

Independensi pemeriksa pajak merupakan sikap yang diharapkan dari seorang pemeriksa pajak dalam melaksanakan tugasnya sesuai dengan standar pemeriksaan yang bertujuan untuk menguji kelayakan secara keseluruhan dan tujuan audit lain (Darosi, 2009).

\section{H2 : Pengalaman Kerja Berpengaruh Positif Terhadap Kualitas Audit Pajak}

Pengalaman merupakan suatu proses pembelajaran dan penambahan perkembangan potensi bertingkahlaku baik dari pendidikan formal maupun non formal atau bisa diartikan sebagai suatu proses yang membawa seseorang kepada suatu pola tingkahlaku yang lebih tinggi. Pengalaman merupakan atribut yang penting yang dimiliki oleh pemeriksa pajak, hak ini terbukti dengan tingkat kesalahan yang dibuat oleh auditor yang tidak berpengalaman (Salim, 2011). Sebagai pemeriksa pajak, pengalaman akan terus meningkat seiring dengan semakin banyaknya penugassan audit dan semakin kompleknya jenis dan usaha wajib pajak yang diaudit sehingga memperluas pengetahuan dibidangnya.

\section{H3: Profesionalisme Berpengaruh Positif Terhadap Kualitas Audit Pajak}

Profesionalisme yang berpengaruh terhadap kualitas audit menunjukkan suatu fenomena bahwa suatu sikap auditor yang professional dalam melaksanakan tugasnya akan mampu memberikan nilai tambah untuk dapat meningkatkan kaualitas audit (Satria dkk, 2012).

H4: Komitmen Organisasi Berpengaruh Positif Terhadap Kualitas Audit Pajak 
Komitmen merupakan salah satu pendukung suatu kinerja yang professional, memiliki komitmen akan menjadikan suatu dorongan bagi seseorang untuk bekerja lebih baik atau sebaliknya dapat menyebabkan sesorang justru meninggalkan pekerjaannya, akibat terdapat suatu komitmen lain. Jadi semakin tinggi tingkat komitmen organisasi seorang pemeriksa pajak maka semakin baik kualitas audit pajak yang dilakukan (Carolita \& Rahardjo, 2012).

H5: Pengaruh Pengalaman, Independensi, Profesionalisme, dan Komitmen Organisasi Auditor Pajak Secara Signifikan Terhadap Kualitas Audit

Sikap pemeriksa yang independen dan professional didukung dengan pengalaman serta sikap yang mempunyai komitmen atas organisasi memberikan pengaruh yang nyata terhadap hasil laporan yang dihasilkan sesuai dengan penelitian yang dilakukan darosi (2009) yang menunjukkan bahwa Independensi, kompetensi, dan etika secara simultan berpengaruh terhadap kualitas audit, sejalan dengan penelitian Carolita \& Rahardjo (2012) yang menunjukkan bahwa pengalaman kerja, independensi, kompetensi, dan etika secara simultan berpengaruh terhadap kualitas audit, sejalan dengan penelitian Carolita \& Rahardjo (2012) yang menunjukkan bahwa pengalaman kerja, independensi, objektifitas, integritas, kompetensi, dan komitmen organisasi berpengaruh terhadap kualitas audit.

\section{Metode}

Desain penelitian ini menggunakan metode deskriftif analitis dengan tipe hubungan kausal. Menurut Sugiyono (2011), hubungan kausal adalah hubungan sebab akibat, bila $\mathrm{X}$ maka $\mathrm{Y}$. Penelitian ini diharapkan dapat menjelaskan keterkaitan antara independensi auditor, pengalaman auditor, profesionalisme auditor, dan komitmen organisasi auditor sebagai variabel independen dengan kualitas hasil audit pajak sebagai variabel dependen. Data dan informasi yang dikumpulkan dari responden melalui penyebaran kuesioner. Setelah data diperoleh, hasilnya akan dipaparkan secara deskriftif, yang selanjutnya akan di analisis untuk menguji hipotesis yang telah diajukan dalam penelitian ini. Jenis data yang digunakan dalam penelitian ini, adalah data primer yaitu data yang diperoleh atau didapat secara langsung dari sumbernya.

Adapun data dalam penelitian ini didapat dari pendapat responden melalui kuesioner kepada seluruh Fungsional Pemeriksa Pajak yang bertugas di Kanwil Jakarta Khusus dan KPP dibawah Kanwil Jakarta Khusus yang sudah ditentukan sebagai sampel. Sebagaimana data primer masih merupakan data ordinal yang masih perlu ditransformasikan menjadi data interval. Disamping itu, data penelitian ini termasuk data kualitatif. Data kualitatif ini diperoleh melalui penyebaran kuisioner yang kemudian diubah menjadi data kuantitatif, diangkakan berupa skoring untuk masing-masing pernyataan dan skala yang digunakan dalam penelitian ini untuk pembobotan item kuesioner adalah menggunakan skala likert dengan menggunakan item positif untuk keseluruhan pernyataan. Adapun tingkatan skoring dapat dilihat pada tabel 1 .

Tabel 1. Skoring Jawaban Responden dengan skala penilaian

\begin{tabular}{clc}
\hline No. & Kriteria & Nilai/skor \\
\hline 1 & Sangat setuju & 5 \\
2 & Setuju & 4 \\
3 & Kurang Setuju & 3 \\
4 & Tidak Setuju & 2 \\
5 & Sangat Tidak Setuju & 1 \\
\hline
\end{tabular}

Populasi dalam penelitian ini adalah para pejabat fungsional pemeriksa pajak Kanwil Jakarta Khusus, hingga akhir tahun 2015 tercatat sebanyak 498 yang merupakan pejabat aktif. Tidak semua Pejabat fungsional pemeriksa pajak menjadi objek penelitian karena pada saat penyebaran kuisioner, para pejabat melakukan dinas luar. Hal ini dilakukan untuk mengoptimalkan penyebaran kuesioner langsung 
kepada para responden. Dalam penelitian ini untuk memperoleh jumlah sampel digunakan rumus (Sugiyono, 2011) sebagai berikut:

$\mathrm{n}=\frac{\mathrm{N}}{\mathrm{Nd}^{2}+1}$

Keterangan :

$\mathrm{n}$ : Jumlah Sampel

$\mathrm{N}$ : Ukuran Populasi

d : Presisi yang ditetapkan sebesar (0.1) dalam penelitian ini jumlah populasi sebanyak 498 orang fungsional pemeriksa pajak, maka berdasarkan formula diatas diperoleh ukuran sampel:

$$
\begin{aligned}
& \mathrm{n}=\frac{498}{1+498(0,01)^{2}} \\
& \mathrm{n}=\frac{498}{5,98} \\
& \mathrm{n}=83,28 \text { (dibulatkan } 83 \text { orang) }
\end{aligned}
$$

Berdasarkan rumus tersebut diatas, maka sampel penelitian ini adalah minimal 83 orang.

Sebagaimana data primer masih merupakan data ordinal yang masih perlu ditransformasikan menjadi data interval. Menurut Kuncoro dan Riduwan (2008), menyatakan bahwa mentransformasikan data interval bertujuan untuk memenuhi sebagian dari syarat analisis parametrik, dimana data sebaiknya berskala interval. Metode yang paling sederhana adalah dengan menggunakan MSI (Method of Succesive Interval).

Data yang diperoleh dari responden perlu di uji validitas dan reliabilitasnya untuk menghindari hal-hal yang bisa dan meragukan keabsahan penelitian ini, maka diperlukan pengujian-pengujian terhadap alat ukur tersebut. Uji validitas dan reliabilitas untuk memenuhi persyaratan utama yaitu: 1) valid dan shahih, 2) reliable atau handal, 3) praktis (Cooper et al., 2006)

Teknik analisis statistik dalam penelitian ini menggunakan regresi berganda (multiple linear regression), sebelum melakukan analisis regresi linear berganda terlebih dahulu dilakukan uji statistik deskriptif dan uji asumsi klasik. Uji statistik deskriptif digunakan untuk mendeskriptifkan secara ringkas variabelvariabel dalam penelitian ini. Analisis deskriptif dilakukan untuk mengetahui gambaran atau deskriptif suatu data yang akan dianalisis (Ghozali, 2011).

Analisis yang akan digunakan dalam penelitian ini adalah analisis berganda, maka perlu dilakukan pengujian terhadap asumsiasumsi yang diperlukan dalam analisis regresi berganda (Hengky \& Selva, 2013). Uji asumsi klasik terdiri dari uji normalitas, uji multikolinearitas, dan uji heteroskedastisitas.

Model pengujian menggunakan metode analisis regresi berganda. Hal ini akan menunjukkan hubungan (korelasi) antara kejadian satu dengan kejadian yang lainnya. Karena terdapat lebih dari dua variabel, maka hubungan linier dapat dinyatakan dalam persamaan regresi linier berganda (Hengky \& Selva, 2013). Pada penelitian ini menggunakan analisis regresi berganda untuk mengetahui pengaruh variabel independen (independensi, pengalaman, profesionalisme dan komitmen organisasi) terhadap kualitas audit pajak, dengan persamaan regresi yang digunakan untuk menguji hipotesis adalah sebagai berikut :

Rumus :

$$
\mathrm{Y}=\mathrm{a}+\mathrm{b} 1 \mathrm{X} 1+\mathrm{b} 2 \mathrm{X} 2+\mathrm{b} 3 \mathrm{X} 3+\mathrm{b} 4 \mathrm{X} 4+\mathrm{e}
$$

Keterangan :

$$
\begin{array}{ll}
\mathrm{Y} & =\text { Kualitas audit pajak } \\
\mathrm{a} & =\text { Konstanta } \\
\mathrm{b} 1, \mathrm{~b} 2, \mathrm{~b} 3, \mathrm{~b} 4 & =\text { Koefisien regresi } \\
\mathrm{X} 1 & =\text { Independensi } \\
\mathrm{X} 2 & =\text { Pengalaman } \\
\mathrm{X} 3 & =\text { Profesionalisme } \\
\mathrm{X} 4 & =\text { Komitmen organisasi } \\
\mathrm{e} & =\text { Disturbance error }
\end{array}
$$

Koefisiensi determinasi $\left(\mathrm{R}^{2}\right)$ adalah untuk mengukur seberapa jauh kemampuan model dalam menerangkan variasi variabel dependen. Nilai $\mathrm{R}^{2}$ adalah diantara nol dan satu. Nilai $\mathrm{R}^{2}$ yang kecil berarti kemampuan variabel $\mathrm{X}_{1}$, 
$\mathrm{X}_{2}, \mathrm{X}_{3}, \mathrm{X}_{4}$ dalam menjelaskan variasi variabel kualitas audit pajak amat terbatas. Sedangkan nilai yang mendekati satu berarti variabel $\mathrm{X}_{1}$, $\mathrm{X}_{2}, \mathrm{X}_{3}, \mathrm{X}_{4}$ memberikan hampir semua informasi yang dibutuhkan untuk memprediksi variabel kualitas audit pajak (Hengky \& Selva, 2013). Uji F merupakan suatu uji yang bertujuan untuk mengetauhi apakah semua variabel independen yang dimasukkan dalam model regresi mempunyai pengaruh secara simultan (bersamasama) terhadap variabel dependen atau tidak. Jika nilai sginifikasi yang dihasilkan uji $\mathrm{F}$ P $<$ 0,05, maka dapat disimpulkan bahwa semua variabel independen secara simultan berpengaruh signifikan terhadap variebl dependen (Hengky \& Selva, 2013). Uji t merupakan suatu uji yang digunakan untuk mengetahui secara parsial pengaruh variabel independen dengan variabel dependen. Jika nilai signifikasi yang dihasilkan uji t $\mathrm{P}<0,05$, maka dapat disimpulkan bahwa secara parsial variabel independen berpengaruh signifikan terhadap variabel dependen (Hengky \& Selva, 2013).

\section{Hasil Penelitian dan Pembahasan}

Pengaruh independensi, pengalaman, profesionalisme dan komitmen organisasi terhadap kualitas audit pajak pada DJP Kanwil Jakarta Khusus secara parsial dan simultan dapat diketauhi melalui pengujian terhadap garis regresi dengan hipotesis. Hasil pengujian terangkum dalam tabel 2.

\section{Pengaruh Independensi Pemeriksa Pajak terhadap Kualitas Audit Pajak.}

Berdasarkan hasil pengujian, nilai tersebut lebih besar daripada $t$ tabel yaitu 2,692. Karena $\mathrm{t}$ hitung $>\mathrm{t}$ tabel, maka Ho ditolak yang artinya dapat disimpulkan bahwa terdapat hubungan yang positif dan signifikan antara variabel independensi dan kualitas audit pajak pada kantor DJP Kanwil Jakarta Khusus. Temuan ini konsisten dengan hasil penelitian Darosi (2009) yang juga menunjukkan bahwa independensi pemeriksa pajak berpengaruh positif terhadap kualitas audit. Jika seorang pemeriksa pajak bersikap independen, maka ia akan memberikan penilaian senyatanya terhadap SPT yang diperiksa, tanpa memiliki beban apapun terhadap pihak manapun. Maka penilaiannya akan mencerminkan kondisi yang sebenarnya dari sebuah perusahaan yang diperiksa, jika sikap independensi ini dapat ditingkatkan oleh para pemeriksa pajak maka kualitas audit yang dihasilkan akan semakin baik.

Hasil penelitian ini tidak mendukung penelitian Carolita \& Rahardjo (2012) dan penelitian Futri \& Juliarsa (2014) yang menyatakan bahwa independensi secara parsial tidak mempunyai pengaruh signifikan terhadap kualitas audit. Namun penelitian ini sejalan dengan hasil penelitian Darosi (2009) yang mengemukakan bahwa independensi berpengaruh positif dan signifikan terhadap kualitas audit pajak. Demikian pula penelitian

Table 2. Hasil Pengujian

\begin{tabular}{lllll}
\hline Keterangan & Std. Beta & Std. Error & t-hitung & Sig \\
\hline Independensi & 0.226 & 0.077 & 2.692 & 0.008 \\
Pengalaman & 0.169 & 0.106 & 2.089 & 0.039 \\
Profesionalisme & 0.048 & 0.083 & 0.612 & 0.542 \\
Komitmen Organisasi & 0.430 & 0.058 & 6.032 & 0.000 \\
R square & 0.434 & & & \\
AdjustedR-square & 0.417 & & & \\
F-Hitung & 25.648 & & & \\
Sig F & 0.000 & & & \\
Ttabel & 1.977 & & & \\
\hline
\end{tabular}


yang dilakukan oleh Singgih \& Bawono (2010) mengemukakan independensi berpengaruh positif dan signifikan terhadap kualitas audit.

\section{Pengaruh Pengalaman Pemeriksa Pajak terhadap Kualitas Audit Pajak}

Nilai hitung lebih besar daripada t tabel yaitu sebesar $2.089>\mathrm{t}$ tabel maka Ho ditolak yang artinya dapat disimpulkan bahwa terdapat hubungan yang signifikan antara variabel pengalaman pemeriksa pajak dan kualitas audit pada Kanwil Jakarta Khusus. Temuan ini konsisten dengan hasil penelitian carolita \& rahadjo (2012) yang menyatakan bahwa pengalaman pemeriksa pajak berpengaruh positif dan signifikan terhadap kualitas audit pajak.

Pengalaman pemeriksa pajak akan terus meningkat seiring dengan makin banyaknya audit yang dilakukan serta komplektisitas transaksi keuangan perusahaan yang diaudit sehingga menambah dan memperluas pengetahuannya dibidang akuntansi dan auditing (Salim 2011). Jika seorang auditor memiliki pengalaman yang banyak, penilaiannya akan mencerminkan kualitas yang baik dari sebuah perusahaan yang diperiksa. Dengan demikian maka jaminan atas keandalan laporan yang diberikan oleh auditor atau pemeriksa pajak tersebut dapat dipercaya oleh semua pihak yang berkepentingan, maka semakin tinggi pengalaman seorang pemeriksa pajak maka kualitas audit pajak yang diberikan semakin baik.

Hasil penelitian ini menunjukkan hasil yang sejalan dengan pendapat (Singgih \& Bawono, 2010) yang mendefinisikan pengalaman sebagai jumlah jam terbang seorang auditor yang dapat memberikan kualitas audit yang lebih baik daripada seorang auditor yang baru memulai karirnya. Pengalaman merupakan atribut yang penting yang dimiliki oleh audit, hal ini terbukti dengan tingkat kesalahan yang dibuat oleh auditor yang tidak berpengalaman lebih banyak daripada auditor yang berpengalaman.
Hal ini tidak sejalan dengan penelitian yang dilakukkan oleh Singgih \& Bawono (2010) dan Futri \& Juliarsa (2014) yang mengatakan bahwa pengalaman tidak berpengaruh signifikan terhadap kualitas audit. Namun penelitian ini sejalan dengan penelitian yang dilakukan Carolita \& Rahardjo (2012) yang menyatakan bahwa pengalaman kerja mempunyai pengaruh positif dan signifikan terhadap kualitas audit. Demikian pula dengan penelitian yang dilakukan oleh (Salim, 2011) yang mengemukkan pengalaman kerja berpengaruh positif dan signifikan terhadap kualitas audit.

\section{Pengaruh Profesionalisme Pemeriksa Pajak terhadap Kualitas Audit Pajak}

Hasil perhitungan nilai t hitung sebesar $0.612<\mathrm{t}$ tabel, maka Ho diterima yang artinya dapat disimpulkan bahwa tidak terdapat hubungan yang tidak signifikan antara variabel profesionalisme pemeriksa pajak dan kualitas audit pajak pada DJP Kantor Wilayah Jakarta Khusus. Temuan ini didukung oleh penelitian Futri \& Juliarsa (2014) yang menyatakan bahwa profesionalisme pemeriksa pajak tidak berpengaruh signifikan terhadap kualitas audit pajak.

Variabel profesionalisme pemeriksa pajak mencakup penguasaan pengetahuan dengan ruang lingkup yang luas, mencakup sifat manusia, kecenderungan sejarah dan lingkungan hidupnya, serta adanya disiplin etika yang dikembangkan dan diterapkan oleh kelompok anggota yang menyandang profesi (Primaningsih, 2010). Dengan menyandang sebagai profesi tertentu maka suatu pekerjaan dituntut professional, Harapan wajib pajak terhadap tuntutan transparansi akan terpenuhi jika auditor dapat menjalankan profesionalisme dengan baik sehingga wajib pajak dapat menilai kualitas audit.

Hasil penelitian ini tidak sejalan dengan pendapat (Primaningsih, 2010) yang mendefinisikan profesionalisme sebagai penggunaan kemahiran professional secara cermat dan 
seksama, dimana menggunakan pertimbangan yang sehat dalam melakukan setiap pemeriksaan. Sehingga sikap profesionalisme dapat memberikan kualitas audit yang baik. Namun penelitian ini sejalan dengan penelitian Futri \& Juliarsa (2014) yang menyatakan bahwa profesionalisme tidak berpengaruh terhadap kualitas audit.

Untuk meningkatkan kualitas audit, seorang auditor dituntut agar bertindak professional dalam melakukan pemeriksaan. Auditor yang professional akan lebih baik dalam menghasilkan audit yang dibutuhkan dan berdampak pada peningkatan kualitas audit. Adanya peningkatan kualitas audit maka meningkat pula kepercayaan wajib pajak terhadap pemeriksa pajak. Dengan demikian profesionalisme perlu ditingkatkan, karena sangat penting dalam melakukkan pemeriksaan sehingga akan memberikan pengaruh pada kualitas audit. Harapan wajib pajak terhadap tuntutan transparansi akan terpenuhi jika auditor dapat menjalankan profesionalisme dengan baik sehingga wajib pajak dapat menilai kualitas audit.

\section{Pengaruh Komitmen Organisasi Pemeriksa Pajak terhadap Kualitas Audit Pajak.}

Hasil perhitungan nilai t hitung $6.032>$ $\mathrm{t}$ tabel, maka Ho ditolak yang artinya dapat disimpulkan bahwa terdapat hubungan yang positif dan signifikan antara variabel Komitmen Organisasi pemeriksa pajak dan kualitas audit pajak pada DJP Kanwil Jakrta Khusus. Temuan ini didukung oleh penelitian dengan Carolita \& Rahardjo, 2012 ) yang menyatakan bahwa Komitmen Organisasi pemeriksa pajak berpengaruh signifikan terhadap kualitas audit.

Komitmen Organisasi pemeriksa pajak sebagai salah satu pendukung suatu kinerja yang professional. Memiliki komitmen akan menjadikan suatu dorongan bagi seorang pemeriksa untuk bekerja lebih baik atau sebaliknya dapa menyebabkan pemeriksa pajak justru meninggalkan pekerjaannya, akibatnya terdapat suatu komitmen lain.Kualitas Audit diukur dengan proksi hasil pemeriksaan, hasil pemeriksaan diukur dari kegiatankegiatan yang dilakukan pemeriksa pada tahap pemeriksaan yang meliputi: Kompetensi, tepat waktu, auditor yang bekerja dengan sikap jujur, bertanggungjawab dan objektif dapat memberikan hasil temuan yang handal, pendapat dan kesimpulan yang sesuai dengan peraturan perundang-undangan perpajakan.

Hasil penelitian ini sejalan dengan penelitian Carolita \& Rahardjo (2012) yang menyatakan komitmen organisasi berpengaruh positif dan signifikan terhadap kualitas audit. Demikian pula penelitian yang dilakukan Cahyani \& Yuniawan (2010) yang mengemukkan terdapat pengaruh positif dan signifikan antara komitmen orrganisasi dengan kinerja karyawan. Jadi semakin tinggi komitmen organisasi seorang pemeriksa pajak maka kualitas audit dilakukan akan semakin tinggi.

Pengaruh Independensi, Pengalaman, Profesionalisme, dan Komitmen Orga-nisasi Pemeriksa Pajak terhadap Kualitas Audit Pajak

Hasil uji penelitian ini membuktikan bahwa secara simultan variabel independensi, pengalaman, profesionalisme dan komitmen organisasi berpengaruh signifikan terhadap kualitas audit pajak di Kanwil Jakarta Khusus dan seluruh KPP dibawahnya. Hal ini berarti dengan adanya independensi dari pemeriksa pajak dalam melakukan persiapan pemeriksaan dan pelaksanaan pemeriksaan, adanya pengalaman pada seorang pameriksa pajak dalam menyelesaikan audit, kemudian adanya sikap profesionalisme pada seorang pemeriksa pajak, serta didukung pemeriksa pajak yang mempunyai komitmen terhadap organisasinya. Keempat faktor ini akan sangat membantu dalam menghasilkan kualitas audit pajak yang berkualitas pada DJP Kanwil Jakarta Khusus dan seluruh KPP dibawahnya. 
Hasil penelitian ini sejalan dengan pendapat De Angelo (1981) dalam Darosi (2009) yang mendefinisikan kualitas audit sebagai probabilitas dimana seorang auditor menemukan dan melaporkan tentang probabilitas dimana seorang auditor menemukan dan melaporkan tentang adanya suatu pelanggaran dalam sistem akuntansi kliennya. Dari pengertian tentang kualitas audit dapat disimpulkan bahwa kualitas audit merupakan segala kemungkinan (probability) dimana auditor pada saat mengaudit laporan keuangan klien dapat menemukan pelanggaran yang terjadi dalam sistem akuntansi klien dan melaporkannya dalam laporan keuangan audit, dimana dalam melaksanakan tugasnya tersebut auditor berpedoman pada standar auditing dan kode etik yang relevan.

Kualitas audit pajak diukur dengan proksi hasil pemeriksaan. Hasil pemeriksaan diukur dari kagiatan-kegiatan yang dilakukan pemeriksa pada tahap pemeriksaan yang meliputi: kompetensi, tepat waktu, auditor yang bekerja dengan sikap jujur, bertanggungjawab dan objektif, dapat memberikan hasil temuan yang handal, pendapat dan kesimpulan yang sesuai dengan Peraturan Perundang-undangan Perpajakan.

Berdasarkan hasil jawaban kuisioner atas alat ukur diatas dapat disimpulkan bahwa variabel independensi, pengalaman, profesionalisme, dan komitmen organisasi secara bersama-sama (simultan) ber-pengaruh terhadap kualitas audit pajak. Hal ini ditunjukkan dengan nilai probabilitas yang jauh lebih kecil dari 0.05. Akan tetapi pemeriksa pajak dalam menghasilkan kualitas audit masih ada pemeriksa pajak yang dalam menyelesaikan pemeriksaan belum tepat waktu dan adanya hasil pemeriksaan yang tidak dapat dipertahankan dihadapan penelaah keberatan dan pengadilan pajak.

\section{Simpulan, Keterbatasan, dan Implikasi Hasil Penelitian.}

Berdasarkan hasil penenlitian dan pembahasan yang telah diuraikan, maka dapat ditarik kesimpulan sebagai berikut:

1. Independensi pemeriksa pajak berpengaruh positif dan signifikan terhadap kualitas audit pajak. Karena Independensi pemeriksa pajak merupakan sikap yang diharapkan dari seorang pemeriksa pajak dalam melaksanakan tugasnya sesuai dengan standar pemeriksaan yang bertujuan untuk menguji kelayakan secara keseluruhan dan tujuan audit lain.

2. Pengalaman pemeriksa pajak berpengaruh positif dan signifikan terhadap kualitas audit pajak. Hal ini disebabkan kebanyakan orang memahami bahwa semakin banyak jumlah jam terbang pemeriksa pajak tentunya akan memberikan kualitas audit yang lebih baik daripada pemeriksa pajak yang baru memulai karirnya.

3. Profesionalisme pemeriksa pajak tidak berpengaruh signifikan terhadap kualitas audit pajak. Hal ini disebabkan profesi pemeriksa dimana dalam melaksanakan tugas dan pekerjaannya terikat dengan standar yang berlaku di Kementrian Keuangan khususnya Direktorat Jenderal Pajak.

4. Komitmen Organisasi pemeriksa pajak berpengaruh positif dan signifikan terhadap kualitas audit pajak. Hal ini dikarenakan pemeriksa pajak harus memiliki keyakinan yang pasti untuk mewujudkan tujuan organisasi dan menumbuhkan loyalitas.

5. Independensi,pengalaman, profesionalisme, dan komitmen organisasi secara simultan berpengaruh signifikan terhadap kualitas audit pajak.

Keterbatasan dalam penelitian ini sulit untuk dihindari, walaupun demikian penelitian ini telah dilakukan sesuai dengan prosedur dan rencana penelitian. Keterbatasan yang dialami selama penelitian ini adalah penyebaran kuisioner yang hanya dilakukan di KPP dibawah Kanwil Jakarta Khusus, dengan sampel responden yang berasal dari 4 KPP dari 9 KPP yang berada dibawah Kanwil Jakarta Khusus. 
Sampel responden yang kurang banyak dari total populasi, dimana total responden masih dibawah $50 \%$ dari total populasi. Hal ini dikarenakan waktu penyebaran kuesioner yang bebarengan dengan kegiatan pemeriksaan lapangan yang padat oleh fungsional pemeriksa pajak, pada beberapa pertanyaan di kuisioner tidak dapat dipahami secara jelas oleh responden untuk menilai pemenuhan atribut kualitas audit pemeriksa pajak di Kanwil DJP Jakarta Khusus sehingga memungkinkan jawaban menjadi bias.

Penelitian selanjutnya disarankan untuk dapat memperluas sampel penelitian dengan mempertimbangkan wilayah, yang mana setiap wilayah dan daerah memiliki karakteristik jenis wajib pajak yang berbeda-beda yang berpengaruh terhadap kualitas audit yang dihasilkan oleh setiap pemeriksa pajak, memperhatikan nilai koefisien determinasi $\left(\mathrm{R}^{2}\right)$ sebesar $41,7 \%$, maka kualitas audit dipengaruhi oleh variabel lain sebesar 58,3\%. Oleh karena itu, disarankan peneliti selanjutnya mengkaji variabel-variabel lain diluar variabel yang diteliti.

Perlu dilakukan evaluasi secara berkesinambungan atas kemampuan individu auditor dengan mengadakan pelatihan baik secara internal maupun eksternal atas kemampuan teknis pemeriksa pajak. Disamping itu perlu dilakukan pelatihan non teknis seperti peningkatan mental dan spiritual untuk mencapai tingkat profesionalisme yang diinginkan dan mampu meningkatkan komitmen terhadap organisasi dalam meningkatkan kualitas audit yang baik.

Fungsional pemeriksa pajak diwajibkan menuangkan semua informasi yang update mengenai WP ( Wajib Pajak ) yang diperiksa pada saat melakukan identifikasi masalah, menentukan cakupan pemeriksaan serta menyusun audit plan rencana program pemeriksaan sebelum melakukan pemeriksaan, selain itu fungsional pemeriksa pajak harus memiliki kompetensi dalam hal pemeriksaan lapangan maupun kantor sehingga hasil laporan pemeriksaan dapat dipertanggungjawabkan secara objektif dan handal.
Sebaiknya target penerimaan pajak dari kegiatan pemeriksaan ditiadakan agar kualitas audit tetap terjaga, karena berdasarkan penelitian ini variabel profesionalisme tidak berpengaruh signifikan terhadap kualitas audit yang disebabkan oleh profesi pemeriksa dimana dalam melaksanakan tugas dan pekerjaannya terikat dengan standar yang berlaku di Kementrian Keuangan Khususnya Direktorat Jendral Pajak

\section{Daftar Referensi}

Anonim, Peraturan Direktur Jenderal Pajak Nomor PER-23/PJ/2013 Tentang Standar Pemeriksaan Pajak

Anonim, Peraturan Menteri Keuangan Nomor 17/PMK.03/2013 Tentang Tata Cara Pemeriksaan.

Anonim, Surat Edaran Direktur Jendral Pajak Nomor SE-11/PJ/2013 Tentang Rencana dan Strategi Pemeriksaan Tahun (2013).

Anonim, Undang-Undang Nomor 6 Tahun (1983) sebagaimana telah diubah terakhir dengan Undang-Undang Nomor 16 Tahun (2009) Tentang Ketetntuan Umum dan Tata Cara Perpajakan.

Carolita, Metha K., Rahardjo., Shiddiq N., (2012). Pengaruh Pengalaman Kerja, Independensi, Objektifitas, Integritas, Kompetensi, dan Komitmen Organisasi Terhadap Kualitas Hasil Audit (Studi Pada Kantor Akuntan Publik di Semarang), Diponegoro Journal Of Accounting Volume 1, Nomor 2 Hal 1-11.

Cooper, D. R., dan Pamela S. S., (2006), Business

Research Methods, New York, McGrawHill Company.

Darosi, Taufik, (2009). Pengaruh Variabel Independensi, Kompetensi, Etika Terhadap Laporan Pemeriksaan Pajak dan Implikasinya Pada Kualitas Audit Pajak Pada Kantor Wilayah Direktorat Jendral Pajak Di Jawatimur. Tesis, Magister Akuntansi Universitas Airlangga, Surabaya. DeAngelo, LE (1981). "Auditor Size and Auditor Quality”. Journal of Accounting 
and Economics, Dec, Vol.3 No.3- 183-199.

Futri, Putu Septiani \& Juliarsa, Gede (2014). Pengaruh Independensi, Profesionalism, Tingkat Pendidikan, Etika Profesi, Pengalaman, dan Kepuasaan Kerja Auditor Pada Kualitas Audit Kantor Akuntan Publik di Bali, Bali E-Jurnal Akuntansi Universitas Udayana 7.2 Hal 444-461. ISSN:2302-8556

Ghozali, I., (2011), Aplikasi Analisi Multivariate Program IBM SPSS 19 Edisi 5, Semarang: Badan Penerbit Universitas Diponegoro.

Hengky, L., Selva, T., (2013). Analisi Multivariate Teknik dan Aplikasi Menggunakan Program IBM SPSS 20.0, Edisi Pertama, Alfabeta, Bandung.

Hutagaol, J., (2007). Isu-isu Kontemporer, Edisi Pertama, Graha Ilmu, Yogyakarta

Jensen, M.C., William, H.M., (1976). Revolution, Exit, and Failure of Internal Control Sistem, Journal of Financial Economics Vol.3.

Maharani, Deasy A. \& Herawati, Nurul (2010). Adakah Kesenjangan Antara Harapan Dan Resepsi Wajib Pajak Badan Terhadap Pelaksanaan Pemeriksaan Pajak. Jurnal Akuntansi, Manajaemen Bisnis Dan Sektor Publik ( Jambsp) Vol 6 No.2 Hal 177-196.

Mulyadi dan Puradireja, Kanaka, (2011). Auditing Suatu Pendekatan Terpadu, Jilid I. Jakarta: Penerbit Erlangga.

Negoro, Sasmito Hadi, (2011). Restitusi pajak nakal dilaporkan ke KPK. Siakses pada tanggal 20 Maret 2012 pada pukul 16.05 pada situs Ikatan Konsultan Pajak Indonesia ( IKPI ): http://www.ikpi.or.id/ content/restitusi-pajak-nakal-dilaporkanke-kpk

Primaningsih, Proborini, (2010). Pengaruh Profesionalisme Dan Integrasi Terhadap Efektifitas Kerja Auditor. Tesis, Magister Akuntansi Universitas Pancasila, Jakarta

Ridwan dan Kuncoro, (2008), Analisis Jalur Untuk Riset Bisnis Dengan SPSS, Alfabeta, Bandung

Salim, Anissa R.dkk, (2011). Pengaruh Pengalaman Kerja, Independensi,
Kompetensi, dan Integritas Terhadap Kualitas Audit (Studi Empirirs Pada Kantor Akuntan Publik di Kepulauan Riau, Sumatera Barat dan Riau ) Jurnal Skripsi

Satra, Wira dkk, (2012). Pengaruh Profesionalisme, Independensi, Motivasi, dan Kompleksitas Tugas Terhadap Kualitas Audit Aparat Inspektorat Dalam Pengawasan Keuangan Daerah Se-provinsi Riau. Jurnal Skripsi.

Singgih, Elisha M. \& Bawono, Icuk R., (2010). Pengaruh Independensi, Pengalaman, Due Professional Care dan Akuntabilitas Terhadap Kualitas Audit (Studi Pada Auditor di KAP Big Four Di Indonesia ) Simposium Nasional Akuntansi XIII, Purwokerto.

Sugiono, (2011). Metode Penelitian Kuantitatif, Kualitatif, dan R\&D, Alfabeta, Bandung.

West, Richard, \& Turner, Lynn. (2007), Introducing Communication Theory. Singapore: McGraw Hill.

Zamal, Firdaus, (2009), Korelasi antara Pelatihan Teknis Perpajakan, Pengalaman, dan Motivasi Pemeriksa Pajak dengan Kinerja Pemeriksa Pajak, Jurnal Skripsi 